\title{
Performing Hybrid Identities, Corporeal Style. An Exploration of Three Feminist Latin American Performance Artists
}

\author{
MóNICA BRAdLeY \\ Escuela de Lenguas Modernas \\ Universidad de Costa Rica
}

\begin{abstract}
The following article analyzes the work of three Latin American performance artists: Jesusa Rodríguez, Carmelita Tropicana, and Teresa Hernández. These three artists use their work to resist colonial, capitalist, and patriarchal oppression and bring issues of racism, borderlands, queer sexualities, gender, and neocolonialism into public discourse. Through their stirring performances, they question and push the limits of their own identities and fight against these injustices and stereotypes, often in a satirical way.
\end{abstract}

Key words: Latin America, Feminism, Queer, Lesbian, Post Colonialism, Performance

\section{Resumen}

El siguiente artículo analiza el trabajo de tres artistas latinoamericanas: Jesusa Rodríguez, Carmelita Tropicana y Teresa Hernández. Estas tres artistas usan su trabajo como resistencia colonial, capitalista y de opresión patriarcal, resaltando situaciones de racismo, zonas fronterizas, sexualidades queer, género y neocolonialismo en el discurso público. Por medio de sus actuaciones estimulantes, ellas cuestionan y llevan más allá los límites de sus identidades luchando en contra de estas injusticias y estereotipos, a veces de una manera satírica.

Palabras claves: Latinoamérica, feminismo, queer, lesbiana, poscolonialismo, actuación 
We are always looking across borders, whether national, ethnic, or cultural. The issue is not if, but how, we look. (Taylor 180).

Hybrid catches the fragmentary subject formation of people whose identities traverse different race, sexuality and gender identifications... These hybridized indentificatory positions are always in transit, shuttling between different identity $v$ ectors. (Munoz 31).

This paper explores three different Latina performance artists and their unique and shifting hybridized subject positions, which their work develops from, creates, and alters. Each of these artists cross boundaries of gender, race, class and sexuality to bring us unique and transitory sites of resistance, which are individually inspiring and which, on a collective level, can be truly revolutionary. The artists bring issues of racism, borderlands, queer sexualities and genders, language, colonialism and neocolonialism, and exile into public discourse through their stirring performances. By questioning and pushing the limits of these identities, they "reembody, reconfigure, reinscribe, [and] resignify" them (Diamond 2). As Diamond states, "Re' acknowledges the pre-existing discursive field, the repetition-and the desire to repeat-within the performative present, while 'embody,' 'configure,' 'inscribe,' 'signify,' assert the possibility of materializing something that exceeds our knowledge, that alters the shape of sites and imagines other as yet unsuspected modes of being" (2). For Bhabha this "re" in performance is a subversive mimicry, "a double articulation, a sign that retains the power of resemblance but menaces the authoritative discourse of colonialism by disclosing its ambivalence. Mimicry...is profoundly disturbing to a dominant discourse because it points out the necessity of producing prohibition within in order to reproduce" (49). Thus, by disturbing the dominant discourses, these Latina performers reveal the inconsistencies and incongruencies of homogenized identities through their ironic mimicries while creating hybrid spaces for themselves and other fractured subjects.

In this paper, I use the terms "Latin America" and "Latina" to comment upon a certain shared history of colonial exploitation that led to the use of these terms and to explore "the broad interplay of political, economic, and cultural practices that have shaped Latin American worlds," but I also wish to problematize a homogeneous concept of "Latin America," and avoid what Francis Aparicio has called tropicalization, which is similar to Said's concept of orientalism (Rodriguez xi, Taylor 182). I do not wish to homogenize the unique histories that have occurred within and between different nations and peoples in Latin America. As Sommer writes, "The very rhythm of efforts at solidarity is a cue to the divisions among constituencies usually identified by national origin" (173). The three performance artists, of different classes, races, nations, and sexualities shed some light on the divisions, differences, and shared experiences of Latina women and reveal the distinct geo-political locations and desires of and for their distinctive performances.

Likewise, since lesbian is the signatory term claimed by two of these performance artists, my use of the term "queer" in this paper refers mainly to 
lesbian sexuality (with attitude) as one form of queer identity and the "recognition of "oneself as 'different' and the deliberative rejection of a heterosexist worldview" (Arrizon 133). As Butler writes, "Queer derives its force precisely through the repeated invocation by which it has become linked to accusation, pathologization, insult," and the queer performance artists I will discuss purposefully reject such articulations and insults by embracing this performative term ("Critically" 154). As Butler posits, "If the power of discourse to produce that which it names is linked with the question of performativity, then the performative is the one domain in which power acts as discourse" (153). Yet, it is also important to discuss lesbian sexuality and its distinct meaning for Latina women, which perhaps makes coming out as lesbian even more queer: "Coming out as a Latina lesbian means publicly laying claim to an identity that is simultaneously ethnic and sexual, subversive and strong" (Arrizon 164). Lesbian sexualities offer specific cultural meanings that must be carefully explored and their "multiple specificities" must be represented, for these identities arise out of particular cultural conditions, constraints, and identifications. Thus, race, nationality and ethnicity "compound the issue of lesbian identity for Latina lesbians" (134) and two of the performance artists act out these compounding and interlocking identities in a way the both moves beyond them and redefines them through dazzling excess and subversive language. As Arrizon points out, "Latina queer activists, artists, and intellectuals have a connection with all social protests that shouts of freedom of expression" (133).
Before moving on to the specific performance artists and cultural revolutionaries of Latin America, both in the homeland and in exile, it is important to first discuss performance and performativity and their meaning and role in social resistance and political activism. Indeed, it would seem amiss to exclude the theoretical underpinnings of contemporary performance studies originating in the Western academy even as the focus of this discussion is directed toward Latin America. Perhaps one of the most potent facets of performance in its endeavor toward social change is its insistence on and necessity of a participatory and critically interpretive audience. Judith Butler, a prominent theoretician of performance, engages the possibilities for interpretation, thus the groundwork of performativity, through her deconstruction of gender: "Significantly, if gender is instituted through acts which are internally discontinuous, then the appearance of substance is precisely that, a constructed identity, a performative accomplishment which the mundane social audience, including the actors themselves, come to believe and perform in the mode of belief" (Butler "Performative" 519). Butler's postulation here, that gender is an iterable performance of available symbolic discourses, illuminates the possibility of subversion of dominant narratives of gender construction through alternative performances, sometimes parody, of expected gender roles. The impossibility of exact emulation destabilizes the myth of an always already normal and original essence of gender.

Incorporating Foucault's theories of resistance wherever here is power and the permeating and pervasive 
power relations that exist between every intercourse, one is able to extrapolate from individual gender identities to identities marked by nation, race, ethnicity, location, and collectivity: "In his theoretical notion that all 'I's' are sites where universalized operations of power always press on the subject, he demonstrates (unintentionally) that no one can avoid the realm of the "subjected" (Arrizon 96). Any realization of the ways in which individuals grapple with awareness and resistance to subjugation and through examination of the manner and extent of oppression must lead one to inquire in terms broader than those of the self. Homi Bhabha takes the step from gender to nation in his interrogation of the hegemony of the state:

This turns the familiar two-faced god into a figure of prodigious doubling that investigates the nation-space in the process of articulation of elements: where meanings may be partial because they are in medias res; and history may be half-made because it is in the process of being made; and the image of cultural authority may be ambivalent because it is caught, uncertainly, in the act of 'composing' its powerful image (3).

Ergo the subversion of the state, like that of gender, lies in exposing the impossible contradiction of the cultural mandate through the performance of indentity/ies "other" than the "one", other than that which has been normatively prescribed. Taken in Freudian terms, one exacts a feeling of unheimlich ("terror of the space or race of the other") to the familiar scenario of the status quo, or the heimlich, ("pleasures of the hearth') (2). In the familiarity of the street, of a state sanctioned exhibition or square, in highly trafficked areas of town and country, the presence of installations, art, or performances gain their ability to alter the matrix of what is socially sanctioned through their "ambivalent" performativity (3). Their citational (dis)use of commonly understood and culturally enforced grammars through a re-imagined and differentially articulated syntax and, at times, lexicon of (dis)rupture enters the performing body into a pirated legitimacy, a (re)constructed oppositional pubic identity: "The point is, as soon as performativity comes to rest on a performance, questions of embodiment, of social relations, of ideological interpellations, of emotional and political effects, all become discussable" (Diamond 5). Likewise, queer positionalities and sexualities can also be performatively produced and discussable through parody and mimicry.

Crucial to an understanding of specifically Latin American performance and performativity is a knowledge of and a reckoning with socio-economic, geo-political, and (neo)colonial history/ present of the nation: "Noting that performativity is a constant negotiation between an act in process and a function already instituted, Diamond emphasizes the political contestation of performance in relation to the social body that comprises the sense of history and cultural production" (Arrizon 27). The performances studied here arise out of a specific historical context and reflect their situatedness. The countries, the personal and collective histories of the performers, and the cultural notion of identity and gender, all attempting to subvert and expand, must be carefully 
considered. Likewise, these performers use language itself as a powerful tool to subvert colonial patriarchal oppression: "Although the notion of language as the internalization of the law of the father that necessarily entraps women is analytically exciting, it is not entirely new to Latin American writers, who have long since known that the languages of the colonial powers cannot be used uncritically and that writers are responsible for codifying the new languages that must be forged" (Kaminsky 23-24). Thus, the question of language is very important when addressing these particular artists who are actively codifying and creating new languages by mixing different dialects of both English and Spanish, playing with accents, and subverting the heteropatriarchal languages of the Church and the state. Their use of language carries both their memories and their futures that their art is speaking towards: "Every person who reads this article has an accent. Your accent carries the story of who you are...traces of your life and identity are woven into you pronunciation, your phrasing, your choice of words...someone who is telling you they don't like how you speak is quite likely telling you that they don't like you" (Matsuda in Sommer 169). These artists reclaim and resignify languages and affirm how they speak, by both performing only in Spanish while also changing and queering the language (Rodriguez and Hernandez) as well as by mixing languages unapologetically (Tropicana). As Anzuldúa writes, "I will no longer be made to feel ashamed of existing... I will have my serpent's tongue-my woman's voice, my sexual voice, my poet's voice. I will overcome the tradition of silence," and these women are also overcoming the tradition of silence through their performances (207).

Both present and past colonization in its most violent and insidious manifestations such as multiple wars, annexation, exile, mass migrations, the Catholic Church, syncretism, machismo and marianismo as well as varying levels of opportunity for public existence or social resistance all work together to form a unique perspective through which the performativity of the artists' identities is spoken: "Performativity undermines the easy location of identity in part by undermining the coherence of categories like personal and political, by seeing individual acts as inseparable from complex discursive power relations" (Blocker 25). As Coco Fusco points out, "the state in many Latin American countries...has a particularly physical way of exercising power on the bodies of its citizentry" (Corpus 9). It only makes sense that bodies so fashioned would bear the traces of location in their memory, on their skin, through their art and expression.

Mexico has long been treated by the United States as a buffer zone to southern Central and South America. Exercising powerful economic control over Mexico, the U.S. has kept close watch over Mexican elections, assuring a capitalist democracy-friendly Mexican government. The U.S./Mexican border is heavily guarded with border patrols marked with maquiladoras, U.S. corporate owned textile factories that exploit the bodies of young Mexican women, as well as those of other Central and South Americans who migrate in search of employment. With no regards to health codes, pollution regulations, benefits, or minimum wages, there 
is practically no recourse for those who turn to the factories with nowhere else to go. The North American Free Trade Agreement greatly exacerbated the gap between the rich and the poor, lining the pockets of a tiny political elite while devastating the vast majority of society. "The 90's turned out to be not quite postrevolutionary, and Mexico has been quietly escorted to the antichamber of modernity to sit out this latest political (intraparty assassinations, indigenous insurrections, student strikes) and economic (collapsed financial markets, devaluations) fainting spell" (Rodriguez 404). Mexicans remain in constant economic, political, and social crisis between corruption, debt, poverty, and globalization.

Jesusa Rodriquez uses her performances, often run out of her theatre, El Habito, which she owns with her partner, Liliana Felipe, an Argentinean performer and musician, to produce awareness and opposition to the corruption surrounding Mexican existence: "Frequently, she moves freely among the spectators, asking questions, taking surveys, calling for votes for or against politicians or their platforms...El Habito provides community members with the opportunity to discuss, express rage, recognize shared interests, and formulate strategies for change" (Fusco Corpus 68). Even former President Ernesto Zedillo came to her performance to assess what she was saying about him. Rodriquez, like so many other Latin American performance artists, helps to create an alternative, "imagined community." Imagined communities are Benedict Anderson's conception of the geographically disparate and multifarious communities forged through print culture:
"Performances allow "the predominantly semiliterate audiences...-- that is, the unimagined community of common people or pueblos left out of print cultureto rehearse and enact the imaginings binding them" (Constantino 18).

Furthmore, these unimagined communities have more commonalities through sense of shared history of rebellion against colonial powers rather than the mere geographical devisions of countries and subcontinents stemming from colonial oppression. As Arrizon affirms, "The sense of collective identity ('Latin America') stems less from a history of shared community that form the shared history of opposition to the colonial powers" (2). Jesusa Rodriguez aptly creates a scene of opposition in her performance Barbie: The Revenge of The Devil. She paints her body red, performing with a white face and crimson lipstick, white horns, and a sparkling red thong. "Aye!! How can human beings be so evil!! Homicide, robbery, rape, torture, missing people!!...These are the souls of those who already belong to me: Reagan, Thatcher, Khomeini, Oliver North, Pinochet, Viola, Videla..." (Constantino 238). She goes on to cite McDonalds, General Motors, Sak's, and Macy's as she concocts the perfect punishment for the global planet gone awry. She mixes her poison to a cumbia rhythm and up from the smoke of the dried ice comes, "I pronounce you Barbie" (241). This statement refers to J.L Austin's discussion of performativity of marriage, whereby "I pronounce you...' puts into effect the relation that it names" (Butler "Critically" 153). However, in Rodriguez's performance, she realizes what this speech act has done, and as the smoke clears she realizes her wrath has overtaken her own 
vengeful prowess, "Oh my God!!! What have I done!! She's horrible!! Mass Production!!" (Constantino 242). The cage from whence the original Barbie arose is not filled with self-same Barbies. She takes one after the other, destroying them with various instruments and measures. As she pulls out the last, she remarks, "Wow, you are beautiful! And God made you white...How wonderful!" (242). She clearly sets the stage for critique of the pervasive ways in which foreign neocolonial governments, corporations, and consumerist markets have invaded the homes and minds of Mexico, all along the way setting impossible dreams and standards for the brown hands who ironically consume there materialistic products.

In her piece, "Genesis," Rodriguez creates a dialogue between God and Mother Nature, in which Mother Nature questions God on his creation of "those 'rare ones,' the ones they call 'queers?'...that go against nature" (235). God replies by explaining that "all pleasure derives from certain difference, course, movement," and thus if everyone was the same, life would be tiresome and unbearable. This paradoxical discourse between God and Mother Nature subverts ideas of naturalness by revealing that everything that is considered "natural" must also be unnatural in order to exist; therefore straight cannot exist without its queer counterpart, gender cannot exist without deviation, and life cannot exist without difference. The conversation continues to address consumerism, while God explains that when he gets bored with being God, he goes on vacation and buys some Chanel to wear. It is the boredom with the same-self that urges people to shop, become tourists and find a 'whore' to distract themselves from the monotony of their lives. God then subverts the hetero/homo binary by revealing how all relationships are homosexual:

And so it is satisfying to experience the mutation of ... one opposite to the other through its middle; and finally we see so much familiarity of the opposites amongst themselves that they become more comfortable amongst themselves than with their own kind. And so, 'a straight who goes with another straight' is also homosexual (236).

By revealing how difference allows for movement, which makes life pleasurable and harmonious, God explains his return from the occult, as the "edict of destiny," in a radical way, "which will be even greater as the ways of sexing become even more different" (237). Likewise, if the condition of men and women is unpleasant, pleasure can only exist in the transition from one to the other; so it is the people who transgender that ultimately find peace. Ironically, the Church, then, with all of its prohibition and guilt around sexuality is what makes sex, but particularly queer sex, pleasurable- for there can be no pleasure without doubt. Mother Nature then poses the question, "And so my Lord, must I admit that those 'anti-natures,' the queers, the different ones are my complement?" (237). God affirmatively replies by stating that they "are the mirror," and Mother Nature finishes his statement, "where you are reflected into infinity" (237). She then concludes that it would be good for her faith to not believe in God, and God replies by saying, "How do I know, Mother Nature! I made you so you 
would doubt my existence. If God were man, I would be a woman, if God were queer, he would be the topic of feminist debate...God is queer in order to keep enjoying being God" (238). This ironic discussion of difference, makes us realize that we cannot exist without the Other, whether this other is sexual, religious, racial, or national, thus making the other less of an Other but rather part of our own being. This changes how we understand and react to difference, and performance is one way in which we can change our conceptions of difference to be more inclusive and affirmative, rather than frightening or violent. This carries over to national identities as well.

Cuba is a nation rich in the arts of performance. Its complex history seems to lend itself to the subversive creativity of its people. Cuba was colonized by Spain and the United States, gaining independence is 1902. It then constructed its own socialist government under Fidel Castro in 1959, only to face a crippling U.S. embargo and heightening levels of capitalist infiltration since the fall of the Soviet Union. The stark shifts in government formation and U.S. relations have produced fraught identities for Cubans, many of whom live as refugees and exiles in the very land that subjugates the island. As Cuba's economy becomes almost singularly supported by remittances and tourism, identity becomes an even more tangled field and racial identity gets even more problematic.

As Arrizon notes, "Latino's tendency to marginalize their African and indigenous roots while celebrating their Hispanic heritage is both an outgrowth of colonial subjectivity....The colonized subject continuously abolishes her/his own identity by invalidating the multiple determinates that may intersect within the broader categories of race or nations" (18). Cuban performer, Carmelita Tropicana, sheds light on the internalized racism of the Latin identity as well as the marginalization of lesbian sexuality. In her performance, Milk of Amnesia/Leche de Amnesia, a typical macho, Pingalito (Carmelita in Drag), attempts to bring back the memory of Cuba for Carmelita, whose acculturation and assimilation to the U.S. have been erased by reading some facts about Cuba from the place mat of a Cuban restaurant: "My favorite expression when you want to find out the color of someone you say: Tell me brother where is your grandmother? Which brings us to fact three. Threefourths of Cubans are white, of Spanish Decent, and a lot of these three-fourths have a very dark suntan all year round" (Troyano 55). Tropicana, herself a selfdescribed "mulatto," raises here the issue of color within the nation, even with those who are able to remain on the island, there is a splitting of identity caused by the racist discourses of colonialism. The racism is exacerbated by U.S. relations, whereby those who left the island, overwhelmingly upper class and hence white (largely due to the legacy of slavery in the sugar plantations of Cuba), are able to send money back to their relatives, broadening the gap of rich and poor and leaving those of color with little resources beyond stringent rationing.

This identity is further split by her queer sexuality, which led her to create this "wholly separate self-the outrageous Carmelita Tropicana-to provide the freedom and space she needs to fully explore and accept both 
her ethnic self and her sexuality" (Arrizon 148). The performance piece, Leche de Amnesia, allows for a unique meeting of Alina Troyano (the writer/ artists) and her alter-self Carmelita Tropicana, "to engage in a tête-á-tête where memory, humor, and autobiography become integrated" (150). The alter-ego, the outwardly and confident Tropicana, “turns Troyano's life into a performance masquerade-her tactical interventions call for a redefinition of identity to include a double-bind subject, a discursive hybrid that merges both culture and imagination" (150). Her identity, then, becomes about fluidity between her different selves- sexual, cultural, and racial. She uses her body and subversive language to make space for all the different aspects of herself; Carmelita happens to be the boldest: "Carmelita Tropicana, with her thick Cuban accent is an invention of mimetic correspondence, parody, and cultural resistance" (151). She performs the multiplicity and hybridity of her identity: "Tropicana ends Milk affirming herself as a performance lesbian artist, "a lesbische cubanerin" (109) who embodies an extravagant sense of queerness. As Carmelita Tropicana, the nightclub entertainer, Alina Troyano's identity is queerly reconfigured in a multidimensional fashion" (159).

In Milk, Troyano, as the writer, also describes her experience of exile and the slow amnesia that took place after she left the island of Cuba at seven. She describes the transformation, the processes of trying to remember Cuba, but the eventual assimilation into American culture that became her amnesia. She learned to drink milk, and to perform American so well that she could no longer remember her home. As Blocker writes, "Exile, like the nation, is performatively produced. Like the nation, exile is more than a location (or, more precisely a lack of location). It is a product of a set of meanings that both engage and undermine the narrative of the nation" (Blocker 27). A sense of nation, and therefore, a sense of exile, is performatively produced through the authoritative speech of nationalist discourses. One pledges allegiance to a flag and thereby instantiates his or her own interpellation to subject-citizenry. Narratives of home, government, patriotism, xenophobia, and the imagined homogeneity of a people produce national identities. When, as in Cuba, the dominant political narrative is suddenly transformed through alternative grammars of the state order, personal identities that do not imbibe the new language are often rent asunder. Sometimes voluntarily, other times forcibly, those whose subjectivity is placed oppositionally to the authoritative state must plant roots in a new land. For Troyano, this process was like turning from a messy yet juicy mango to a neat and healthy apple, and her performance is about her struggle to become a mango again, while retaining some characteristics of an apple. "In Milk, the corporeality of memory is central," and only Carmelita has the courage to confront this memory of exile and the wounding sense of loss that triggered her amnesia (Arrizon 152).

Puerto Rico represents a unique geo-political case for Latin America. After the Spanish American War, the U.S. confiscated the island and annexed it to the U.S. for its strategic location in the Caribbean. In 1917, the passage of the Jones Act made Puerto Ricans U.S. Citizens, but did 
not, however, make Puerto Rico a state. Puerto Ricans could be and were drafted into the U.S. wars, but did not gain their independence and selfgovernance. Stifling economic crises on the island caused mass migration to the U.S., with most ending up in New York, prompting the coining of the name Nuyorican to describe the phenomenon: "This colonial bandage evokes the relation, above all, between Puerto Rican people here and there, between the expressive life of the migrant population and the longstanding traditions of the struggle and articulation of the Island culture" (Arrizon 11). The fracturing of a sense of home, cultural unity, and identity caused by migration has paradoxically been the bond for many Puerto Ricans in the Bronx. The Nuyoricans there have performed home in the reconstruction of casitas in the empty lots of the city. Casitas originally came into being along riverbanks in Puerto Rico when peasants and rural persons were displaced by stark and sudden economic changes under American rule and industrialization/ modernization: "Since its earliest use, casita architecture has been eminently portable; casita settlements were built more with the dream than with the real prospect of settling in mind. With displacement the most pressing fact of life, the illusion of permanence becomes paramount" (Taylor 131).

Unlike the Cubans who migrated to North America, Puerto Ricans who arrived did so with little money and the hue of their skin greatly disadvantaged upward mobility upon settling in the U.S. In the forgotten slums of New York, Nuyoricans forged an unimagined community through the building of casitas and the staging of cultural events: "Such social conditions, in addition to their historical symbolism, make casita settings themselves into acts of performative expression...[T] hat performance refers to an act of imaginative transposition, or construction as anticipated provisionality and recontexualization" (132). The casitas are a rich cultural resource for Puerto Rican foods, music, entertainment, and news of the homeland. The community forged through the casitas offers a performative sense of home and belonging in a condition of exile for many Nuyoricans who derive strength, sustenance, and identity through them. They offer a performative memory of Puerto Rico during the times before they were forced by sociopolitical and economic hardships to transplant their lives and these perforative aspects of identity become necessary for cultural survival in such an overwhelmingly assimilationist nation.

In her performance, How Complex Being Is, or, The Complex of Being, Puerto Rican artist Teresa Hernandez draws a powerful, yet humorous, portrait of identity on the island. Impersonating Senator Pardonme of Puerto Rico, she addresses her audience, "With the authority bestowed upon me by the Law and by the Free Associated Statutory ra-... I'm sorry, State, of Puerto Rico... I gratefully and proudly accept this recognition awarded to us by UNESCO and the Commission for the Protection of Tiny Countries, for being the only pre-state country in existence" (Constantino 387-388). She continues her politically charged commentary, "I'm sorry, if anyone here doesn't understand what I'm saying, please interrupt me... With all the going back-and-forth between official 
languages - a few years with this one and a few years with that one-it's a real mess, this thing with the...thing, what's it called...language" (388). She plans to address the problem of Puerto Rico's invisibility by petitioning Congress to advocate a "mandatory inclusion of a magnifying glass along with every map that is manufactured...! Well, actually, not every map, I mean, just the maps we have access to, the maps of the United States" (389). She is certain of her success, however, in that the nation has just had a visit from Donald Trump, who they treated like a King, four Miss Universe pageant winners, and the canonization of the own Saint Charlie, really Carlos, but then that language thing again. She apologizes for the absence of her Sister, Pragma, who couldn't make it to the lecture series, "Shame on You for Being Small." Her other sister, Perpetua, however, was able to make it and enters the stage to sing her original piece, "Escape the Local."

The end of the piece occurs with the introduction of Isabella Fernandez, and art critic and performative experience specialist who arrives to offer a speech: "We are currently in this hemispheric institutional bubble to scratch and scrutinize among ourselves the topic at hand, namely, Performance and Politics in the Americas: Memory, Atrocity, and Resistance" (392). She condemns the Puerto Ricans' "atrocious resistance to memory" that has been adopted as a survival and defense mechanism by so many on the island who have become complacent under U.S. annexation (392). She encourages the audience to insist upon the multiplicity of their identities as more than just colonized subjects, to overcome their psyches of shame and forgetfulness about their political situation. Through the laughs comes an incisive critique of the problems of being termed a Commonwealth of Free Associated State. Even the language with which they must speak has been colonized by the U.S., making understanding and self-reflection and expressivity practically impossible. She comments on "free trade" policies of the U.S. causing the only "maps" Puerto Ricans have access to, to be U.S. maps, and consequently, to a whole range of other "American" products. She illuminates the fraught existence of a small country and begs the audience that they, too, like the larger nations of the earth, should not forget or trivialize their own being.

As one can see, language, cultural identity, gender, sexuality, nationality, race and exile status interlock in each of these performances as they do in the performers' lives. These performers push the boundaries of what is acceptable in society through their fleeting yet enduring performances that fight against these injustices and stereotypes, often in a satirical way: "My analysis complements Chandra Talpade Mohanty's position that the notion of colonization 'almost invariably implies a relation of structural domination, and a suppression-often violent-of the heterogeneitiy of the subject(s) in question" (Arrizon 2). Latin America, like the rest of the world, faces multiple oppressions. The legacy of colonialism, the neo-colonialism of globalization, export trade zones, the World Bank and IMF, overwhelming amounts of debt, and various other U.S. and Western European policies all work together to crush the autonomy of the nations there. Within the countries, women not only face these obstacles, but also the heteropatriarchies, which institutionalize sexism, heterosexism, and racism. The Catholic 
Church and the expected societal roles of the macho and marianismo hegemonically infiltrate the consciousness of Latin Americans, often convincing women that wife and mother is all they can or even hope to become. In such situations, as Foucault has noted, resistance necessarily rises. Performance is a unique weapon for the oppressed in that it is fleeting and unscripted and thereby difficult to trace or censor. That performance can be configured as a one-woman show, a collective skit, a social phenomenon, or a massive political movement is a testament to its hybridity, flexibility, and power. The Latin American performances and performers discussed here "are not simply the subaltern dancing to a dominant tune; nor [are they] a question of an alterity operating at an unconscious level, but a conscious recognition and pursuit of an altogether different set of values and historical and cultural trajectories" (Fusco Bodies 228).

\section{Bibliography}

Anzuldúa, Gloria. "How to Tame a Wild Tongue." Out There: Marginalization and Contemporary Cultures. Ed. Russell Ferguson et al. MIT Press, 1990. 203-212.

Arrizon, Alicia. Latina Performance: Traversing the Stage. Indiana University Press, 1999.

Bhabha, Homi. Nation and Narration. Routledge, 1990.

Blocker, Jane. Where is Ana Mendieta?: Identity, Performativity, and Exile. Duke University Press, 2002.

Butler, Judith. "Performative Acts and Gender Constitution: An Essay in Phenomenology and Feminist
Theory." Theatre Journal, 40.4. (1988): 511-524.

-. "Critically Queer." Performance Studies. Ed. Erin Sriff. Palgrave, 2003. 152-165.

Constantino, Roselyn, and Diana Taylor. Holly Terrors: Latin American Women Perform. Duke University Press, 2003.

Diamond, Elin. Performance and Cultural Politics. Routledge, 1996.

Fusco, Coco. The Bodies that Were Not Ours and Other Writings. Routledge, 2000.

-. Corpus Delecti: Performance Art of the Americas. Routledge, 2000.

Kaminsky, Amy. Reading the Body Politic: Feminist Criticism and Latin American Women Writers. University of Minnesota Press, 1993.

Munoz, Jose Esteban. Disidentifications: Queers of Color and the Performance of Politics. University of Minnesota Press, 2000.

Rodriquez, Ileanna, ed. The Latin American Subaltern Studies Reader. Duke University Press, 2001.

Sommer,Doris. " AmeRícan Accents: Syncopate the State." The Ends of Performance. Ed. Phelan, Peggy, and Jill Lane. New York University Press, 1998. 169-177.

Taylor, Diana, and Juan Villegas, eds. Negotiating Performance: Gender, Sexuality, and Theatricality in Latin/o America. Duke University Press, 1994.

Taylor, Diana. "Border Watching." The Ends of Performance. Ed. Phelan, Peggy, and Jill Lane. New York University Press, 1998. 178-185.

Troyano, Alina. I, Carmelita Tropicana: Performing Between Cultures. Beacon Press, 2000. 